\title{
вмJ Global Health COVID-19: time for paradigm shift in the nexus between local, national and global health
}

\author{
Elisabeth Paul (D) , ${ }^{1,2}$ Garrett W Brown, ${ }^{3}$ Valery Ridde (D) ${ }^{4}$
}

To cite: Paul E, Brown GW, Ridde V. COVID-19: time for paradigm shift in the nexus between local, national and global health. BMJ Global Health 2020;5:e002622. doi:10.1136/ bmjgh-2020-002622

EP and GWB contributed equally.

EP and GWB are joint first authors.

Received 9 April 2020

Accepted 13 April 2020

\section{Check for updates}

(C) Author(s) (or their employer(s)) 2020. Re-use permitted under CC BY-NC. No commercial re-use. See rights and permissions. Published by BMJ.

${ }^{1}$ School of Public Health Université Libre de Bruxelles, Bruxelles, Belgium

${ }^{2}$ Tax Institute, Liege University, Liege, Belgium

${ }^{3}$ Global Health Theme, POLIS, University of Leeds, Leeds, UK ${ }^{4}$ CEPED (IRD-Universités de Paris), INSERM, Institut de recherche pour le developpement, Paris, France

Correspondence to Dr Elisabeth Paul Elisabeth.Paul@ulb.ac.be

\section{INTRODUCTION}

The WHO declared the novel coronavirus disease 2019 (COVID-19) an 'emergency of international concern' on 30 January 2020 and a pandemic on 11 March. According to WHO's Situation Report - 79, as of 8 April 2020, the epidemic has caused 79235 deaths worldwide. ${ }^{1}$ While it is seemingly nearing its end in China, where it was first reported, it is still on the rise in Europe, in the USA and in other parts of the world, including in many low-income and middle-income countries (LMICs). The pandemic has triggered unprecedented measures worldwide. Many countries have installed travel bans, confinement and lockdown policies. These responses have been adopted in an 'emergency' mode, and are largely reactionary, aimed at mitigating the spread of the disease while waiting for a specific cure and/or vaccine to be developed.

Here we do not want to underestimate the risks caused by the pandemic, nor to question the measures taken by the WHO and governments. But we would like to express our concerns regarding four COVID-19-related issues, and advocate for a 'paradigm shift'that is, a scientific revolution encompassing changes in the basic concepts and experimental practices of a scientific discipline ${ }^{2}-$ to prepare for future crises.

\section{A SHIFT IN FOCUS: COVID-19 IN THE BROADER GLOBAL HEALTH PICTURE}

It is important to remember other acknowledged and preventable health conditions, when compared with the focus that COVID-19 has triggered at global and national levels. Respiratory diseases have been leading causes of death and disability in the world before COVID-19. It is estimated that, globally, fourmillion people die prematurely from chronic respiratory disease each year;
Key messages

The COVID-19 pandemic has triggered unprecedented measures worldwide, which have often been adopted in an 'emergency' mode and are largely reactionary

- Alternatively, COVID-19 needs to be appraised as part of a much bigger health picture, adopting a "systems approach" that enables interactions with other acknowledged and preventable health conditions, which often receive disproportionately low attention

- To do so requires a paradigm shift in global health governance, from a specific reactional paradigm to a systemic, coordinated and preventive paradigm

- It is necessary to adopt a holistic approach to health reflecting both a security approach and a health development approach, tackling upstream causes and determinants, aimed at helping populations reduce their individual risk factors and augment their natural immunity

- Such preventive health policies must be tailored to local specificities and local environments, and health systems must be strengthened at the local level so as to be able to respond to population needs and expectations

- The current crisis calls for a paradigm shift in public and global health policies; and in the in the nexus between local, national and global health policies and systems

in particular, onemillion die annually from chronic obstructive pulmonary disease; pneumonia kills millions of people annually and is a leading cause of death among children under 5 years old; each year 1.4 million die from tuberculosis; and lung cancer kills 1.6 million people a year and is the deadliest cancer. $^{3}$ The WHO estimates that seasonal influenza kills up to 650000 people a year. ${ }^{4}$ In 2018, an estimated 405000 people died of malaria. ${ }^{5}$ In 2017, about 295000 women died during and following pregnancy and childbirth-that is approximately 810 women each day. ${ }^{6}$ In the USA alone, a lower limit of 
210000 deaths per year was associated with preventable harm in hospitals. ${ }^{7}$

Whereas infectious diseases seem to inspire the most terror among the public and policymakers, noncommunicable diseases are responsible for almost $70 \%$ of all deaths. ${ }^{8}$ Depression affects 300 million people globally and is the leading cause of disability worldwide, and nearly 800000 people die from suicide every year. ${ }^{9}$ The global boom in premature mortality and morbidity from non-communicable diseases has now reached a point where some have even suggested it to be a pandemic. ${ }^{10}$ Moreover, climate change (through increased heat waves and disasters) and atmospheric and environmental pollution are expected to increase deaths and injuries, especially in LMICs. ${ }^{11}$ In some debates, climate change has become more than a risk factor, with increasing calls for the WHO to declare it a public health emergency. ${ }^{12}$

From a public health perspective, COVID-19 needs to be appraised as part of a much bigger health picture. For instance, beyond the lethality and direct mortality rates of COVID-19, attention should be paid to the interaction with other pathogens, as well as to the more indirect effects of its mitigation measures. ${ }^{13}$ Indeed, the pandemic and its containment measures interact with, and impact on, other health conditions and will have system-wide effects, highlighting the importance of adopting a 'systems approach' to its resolution. ${ }^{14}$

\section{A PARADIGM SHIFT IN GLOBAL HEALTH GOVERNANCE}

The global health community, national security agencies and all governments have known that a pandemic like COVID-19 was likely to come, yet global health policy has remained woefully unprepared nor fit-for-purpose. In 2015, the G7 members proclaimed that Ebola had been a 'wake-up call' for the need for better global cooperation. It was also recognised that antimicrobial resistance (AMR) threatened to kill 300 million people by 2050 , thus demanding urgent action. Yet little has been done to address these existing global health governance shortcomings. ${ }^{15}$

For example, the lauded G7 and G20 response, the Global Health Security Agenda (https://ghsagenda. org/), continues to speak in the terms of costly "countermeasures' versus prevention and health system strengthening. Moreover, the Pandemic Emergency Financing Facility (PEF) (https://www.worldbank.org/en/topic/ pandemics/brief/pandemic-emergency-financingfacility), meant to deliver up to $\$ 500$ million in epidemic assistance to curb expansion into a pandemic, sits idle as a complicated 'loan mechanism' at the World Bank, available to only a few countries (eg, China and India do not qualify for the money). There is also serious ambiguity about how the PEF intersects and/or complements the WHO's Contingency Fund for Emergencies (CFE) (https://www.who.int/emergencies/funding/contingency-fund-for-emergencies). The $\mathrm{CFE}$ is available to more countries for more risks, and more quickly, but represents far less money than the PEF (which, in theory, should come after the CFE, if you happen to prequalify for the loan). ${ }^{16}$ The 'One Health' approach, which was meant to offer a more responsive research and policy agenda to combat zoonotic diseases, remains sluggish at best and underdeveloped in terms of including environmental factors, such as soil and water, which play a crucial part in AMR and other threats. ${ }^{17}$

In terms of pathogen monitoring and response, the 2005 International Health Regulations, which are meant 'to help the international community and governments prevent and respond to acute public health risks that have the potential to cross borders and threaten people worldwide', ${ }^{18}$ are not fully implemented by many countries due to limited financial resources and political will, and have been violated in response to the COVID-19 outbreak. ${ }^{19}$ What is more confounding is that many highincome countries like France have failed to fully implement the International Health Regulations, particularly in their overseas territories. ${ }^{16}$ In addition, other disease control mechanisms, like the WHO Global Influenza Surveillance and Response System (https://www.who. int/influenza/gisrs_laboratory/en/), remain inadequate and underfunded, with too few WHO laboratories and a market-based model where a global public good (pooled influenza knowledge) is turned into a private good (pharmaceutical profit), with historical inequities in terms of public health. ${ }^{20}$ Moreover, many countries, like China, are incentivised not to raise the epidemic alarm too soon due to fears of diminished direct foreign investment (like with severe acute respiratory syndrome, H7N9 and now COVID-19) and fears that the government will be perceived as weak. ${ }^{21}$

These conditions of incapacity at the international level are exacerbated by a weakened WHO, whose budget has been radically reduced and ring-fenced. For example, the WHO used to receive three-quarters of its financing from assessed contributions levied on members. However, a change to a zero real growth policy for its regular budget in the 1980s has meant it now only receives a quarter of its budget from member contributions. As a result, the WHO is dependent on extra-budgetary ring-fenced 'pet project' funding from donors to fill an increasingly shrinking budget. ${ }^{22}$ As the money flows to other multilateral health initiatives, the WHO's authority dissipates, with numerous organisations like the Institute for Health Metrics and Evaluation, the Bill and Melinda Gates Foundation and Médecins Sans Frontières able to command greater epistemic authority, ${ }^{23}$ financial influence ${ }^{24}$ and response effectiveness. ${ }^{25}$ However, this expansion of initiatives creates a condition of policy fragmentation, which significantly weakens coordinated global public health. ${ }^{2627}$

One real result of fragmentation of global health governance is an inefficient division of labour, where hundreds of actors such as the WHO, Global Fund, President's Emergency Plan For AIDS Relief, United Nations Programme on HIV and AIDS, United States Agency 
for International Development, World Bank, the Gates Foundation and the Clinton Foundation (to name only a few) produce parallel programmes or bric-à-brac vertical health silos that have neither generated overall system strengthening in high burden countries nor allowed for effective global health policy. ${ }^{27}{ }^{28}$ This creates two failures. First, contrary to sector-wide approaches, ${ }^{29}$ vertical 'pet-project' global initiatives often fail to promote sustainable long-term local health system strengthening, which is the best preventive defence for disease control (of all types, not just infectious diseases). Second, the global level is woefully unprepared for epidemics, since global policy has remained reactionary, symptom-based and dependent on vaccine discoveries without full appreciation of other upstream determinants of disease and access to those vaccines.

Given the state of global health governance and inadequate investments in health system strengthening-as well as the failure, by many actors, to adopt a 'systems approach' to problem resolution ${ }^{14}$ - the spread and danger of COVID-19 is not surprising. What is required, we argue, is to shift global health policymaking from a specific reactional paradigm to a systemic, holistic and preventive paradigm. There is no doubt that this approach will require serious resources, governance reform and political will. Nevertheless, the global economic costs of COVID-19 have already reached into at least a trillion dollars. ${ }^{30}$ Thus, serious efforts to improve global and local health systems would be a small fraction of this cost, with a tried and true cost-saving philosophy that 'an ounce of prevention is worth a pound of cure'.

\section{BEYOND THE 'PASTEURIAN PARADIGM': A HOLISTIC VIEW OF HEALTH}

The emergency responses to COVID-19 so far are based on the so-called 'Pasteurian paradigm', which states that each disease is due to one pathogen; thus, for each disease there is one cure, targeting the responsible pathogen. In this case, laboratories are racing to find the cure or the vaccine against COVID-19-a vaccine which will come too late for the current epidemic, and will have limited efficacy if the virus mutates in the coming months or years. Yet it is easy to see how the more pathogens there might be in the future (which there will be) the less this paradigm makes sense. Moreover, the Pasteurian paradigm has imposed its preferred research methodnamely, randomised control trials that try to isolate one variable from all possible variables-as the gold standard of science, relegating other approaches as near charlatanism.

However, there is a multitude of evidence indicating that beyond a single pathogen, the development of a disease, as well as its outcome, is considerably affected by the physical and social parameters in which it operates, and that this is considerably affected by social, political, environmental and individual factors. ${ }^{31} 32$ This seems widely known by the public as far as chronic non-communicable diseases are concerned, but is also the case for infectious diseases, especially for emerging infections, in which the pathogenic role of social inequalities is recognised. ${ }^{33}$ Moreover, the traditional frontiers between communicable and non-communicable diseases are being blurred by evidence of 'biosocial contagion'. ${ }^{34}$ In this light, the globalised world is now facing a 'syndemic'-that is, a synergy of epidemics that 'cooccur in time and place, interact with each other to produce complex sequelae, and share common underlying societal drivers'. ${ }^{35}$ COVID-19 is no exception, since its mortality rate varies significantly according to age, sex and comorbidities. ${ }^{36}$

As an alternative, we argue that it would be more effective, efficient and equitable to adopt a holistic approach to health. How to tackle the silent killers and how to prepare populations-including the most vulnerable $^{37}$-against future epidemics should be on the top of national and global health policy and research agendas. This should reflect both a security approach (fighting symptomatic issues) and a health development approach (tackling upstream causes and determinants). In doing so, the objectives should not be merely be the response mode, but a more concerted effort to limit environmental factors, protect biodiversity, ${ }^{38}$ reduce social health inequities, strengthen local health systems for preventive health, help populations reduce their individual risk factors and augment their natural immunity-notably through various 'healthy behaviours' and diets that are proven to strengthen the general immune system. ${ }^{39-46}$ Like what recently took place in the field of evaluation of complex systems and policies, ${ }^{47}$ a 'realist' revolution of medical research is probably needed to help support this.

\section{FROM GLOBAL SOLUTIONS TO LOCAL ADAPTATIONS}

It is ultimately important that the resulting policies are not copy-pasted from other countries, but adapted to each context, and backed by strong local health systems. By definition, preventive health policies must be tailored to local specificities, including local environments, and health systems must be strengthened at the local level so as to be able to respond to a population's needs and expectations. This is also the case for the response to COVID-19. Viruses and epidemics have always existed, and will always exist, and should be anticipated. ${ }^{48} 49$ Coronaviruses are a well-known family of viruses, and even if this one is particularly aggressive, its genome has been rapidly identified. The difference with this epidemic which is causing the semicollapse of health systems is that it has revealed a profound lack of national prevention and preparedness. In response to the epidemic, the most hit countries so far have faced a lack of equipment and critical care beds. In the UK and France, as just two examples, decades of austerity policies and an obsession with evaluating health facilities based on technical efficiency (ie, minimising inputs and increasing outputs) have considerably decreased the capacity of health systems to respond to above-average frequentation. ${ }^{50}$ 
The COVID-19 emergency responses of many states have revealed important inconsistencies. In many European countries, the authorities have adopted a one-sizefits-all policy and imposed the same measures everywhere. More worryingly, some governments-notably in Africahave not performed their own adapted risk assessment before copy-pasting strategies from abroad. ${ }^{51}$ This is problematic, since it makes little sense to use a predictive model developed from a country where the median age is 47 and translate it to a country with a median age of 18 , without adjusting the parameters. In addition, current policies fail to account for regional or transborder contextual parameters, where either more stringent or relaxed measures could be more suitable depending on geographical determinants. The universal lockdown of a whole country may not be necessary when there are only one or two epidemic outbreaks separated by hundreds of miles, especially if containment is quick and determined. What we suggest, in order to be effective, is that policies should fit each context and be adaptive at the territorial or ecosystem level, versus being unreflectively and uniformly bounded by national jurisdictions. This is the best way to not impose measures that are too coercive, which may face legal constraints and may be counterproductive, eroding public trust and cooperation. ${ }^{52} 53$

In the post-COVID-19 recovery phase, we hope the lessons learnt from local, national and global responses to this pandemic will foster support, by policymakers and by the public, for tailored policy responses that support stronger and more integrated local health systems.

\section{CONCLUSION}

In summary, the current crisis calls for a paradigm shift in public and global health policies. We will not be prepared for the next epidemic unless we take bold steps. First, global health policies should not be designed on a response mode to case-by-case threats, but should adopt a systems approach that can support a holistic picture of global disease burdens, risks and health conditions, as well as better consider the system-wide effects of adopted measures. Second, countering current fragmentation in global health governance will require a substantial shift in global health policymaking from a reactional paradigm to a systemic and preventive paradigm, with meaningful commitments to human health security. Third, there is a need to shift our focus from short-term curative policies based on the Pasteurian paradigm, to long-term preventive and promotional policies based on a holistic view of people's health, which notably implies limiting environmental factors, reducing social health inequities, helping populations reduce their individual risk factors and augmenting their natural immunity. Lastly, such holistic, preventive policies must be adapted to local contexts and implemented through strong local health systems able to have the 'cushion' capacity to respond to emergencies.

Twitter Valery Ridde @ValeryRidde
Acknowledgements We thank Seye Abimbola for inviting us to submit this commentary and for giving us critical suggestions for improvement, and Eric Muraille for advising on references on immunity.

Contributors EP and GB both had an initial idea for this paper and joined forces to arrive to this joint paper. They wrote the first draft and VR contributed to improving it. All authors contributed to the development of ideas, commenting on drafts and approved the final version.

Funding The authors have not declared a specific grant for this research from any funding agency in the public, commercial or not-for-profit sectors.

Competing interests EP and VR have conducted consultations for various international and donor agencies. GB and VR have received funding from several research funding agencies. However, this article has been written in total independence of these contracts.

Patient consent for publication Not required.

Provenance and peer review Commissioned; internally peer reviewed.

Data availability statement There are no data in this work.

Open access This is an open access article distributed in accordance with the Creative Commons Attribution Non Commercial (CC BY-NC 4.0) license, which permits others to distribute, remix, adapt, build upon this work non-commercially, and license their derivative works on different terms, provided the original work is properly cited, appropriate credit is given, any changes made indicated, and the use is non-commercial. See: http://creativecommons.org/licenses/by-nc/4.0/.

\section{ORCID iDs}

Elisabeth Paul http://orcid.org/0000-0002-3928-4093

Valery Ridde http://orcid.org/0000-0001-9299-8266

\section{REFERENCES}

1 World Health Organization. Coronavirus disease 2019 (COVID-19) Situation Report - 79 [Internet]. Geneva, Switzerland: World Health Organization, 2020. Available: https://www.who.int/docs/defaultsource/coronaviruse/situation-reports/20200408-sitrep-79-covid-19. pdf?sfvrsn=4796b143_4

2 Kuhn TS. The structure of scientific revolutions. Chicago: University of Chicago Press, 1962.

3 Forum of International Respiratory Societies. The Global Impact of Respiratory Disease - Second Edition [Internet]. Sheffield, UK: European Respiratory Society, 2017. Available: https://www.who.int/ gard/publications/The_Global_Impact_of_Respiratory_Disease.pdf

4 World Health Organization. Up to 650000 people die of respiratory diseases linked to seasonal flu each year [Internet]. News release, 2017. Available: https://www.who.int/news-room/detail/14-122017-up-to-650-000-people-die-of-respiratory-diseases-linked-toseasonal-flu-each-year

5 World Health Organization. World malaria report 2019. Geneva, Switzerland: World Health Organization, 2019.

6 World Health Organization. Trends in maternal mortality 2000 to 2017: estimates by WHO, UNICEF, UNFPA, World Bank Group and the United Nations Population Division [Internet], 2019. Available: http://documents.worldbank.org/curated/en/793971568908763231/ pdf/Trends-in-maternal-mortality-2000-to-2017-Estimates-byWHO-UNICEF-UNFPA-World-Bank-Group-and-the-United-NationsPopulation-Division.pdf

7 James JT, New A. A new, evidence-based estimate of patient harms associated with hospital care. J Patient Saf 2013;9:122-8.

8 World Health Organization. Noncommunicable diseases [Internet], 2020. Available: https://www.who.int/health-topics/ noncommunicable-diseases\#tab=tab_1

9 World Health Organization. Time to deliver - Report of the WHO Independent High-level Commission on Noncommunicable Diseases [Internet]. Geneva, 2018. Available: https://apps.who.int/iris/ bitstream/handle/10665/272710/9789241514163-eng.pdf?ua=1

10 Allen L. Are we facing a noncommunicable disease pandemic? J Epidemiol Glob Health 2017;7:5-9.

11 IPCC. Climate Change 2014: Impacts, Adaptation, and Vulnerability. Part A: Global and Sectoral Aspects. Contribution of Working Group II to the Fifth Assessment Report of the Intergovernmental Panel on Climate Change [Internet]. Cambridge, United Kingdom and New York, NY, USA: Intergovernmental Panel on Climate Change; 2014. (Cambridge University Press). Available: https://www.ipcc.ch/site/ assets/uploads/2018/02/WGIIAR5-PartA_FINAL.pdf 
12 Harmer A, Eder B, Gepp S, et al. Who should declare climate change a public health emergency. BMJ 2020;368:m797.

13 Paul E, Ridde V. Évaluer les effets des différentes mesures de lutte contre le Covid-19, mission impossible? [Internet]. The Conversation, 2020. Available: https://theconversation.com/evaluerles-effets-des-differentes-mesures-de-lutte-contre-le-covid-19mission-impossible-135060\#comment 2189947

14 de Savigny D, Adam T. Systems Thinking for Health Systems Strengthening [Internet]. Alliance for Health Policy and Systems Research and World Health Organization, 2009. Available: http:// www.who.int/alliance-hpsr/resources/9789241563895/en/

15 Brown GW. The 2015 G7 summit: A missed opportunity for global health leadership. Global Policy [Internet], 2015. Available: https:// www.globalpolicyjournal.com/sites/default/files/inline/files/Brown\% 20-\%20The\%202015\%20G7\%20summit,\%20A\%20missed\% 20opportunity\%20for\%20global\%20health\%20leadership.pdf

16 Brown GW, Wills O, Loewenson R. Global emergency financing and health system strengthening [Internet]. Harare: University of Sheffield, TARSC, EQUINET, 2016. Available: https://www. equinetafrica.org/sites/default/files/uploads/documents/EQ\% 20Emergency\%20Funds\%20brief\%202016.pdf

17 Essack SY. Environment: the neglected component of the one health triad. Lancet Planet Health 2018;2:e238-9.

18 World Health Organization. International Health Regulations (2005) Second edition [Internet], 2008. Available: https://apps.who.int/ iris/bitstream/handle/10665/43883/9789241580410_eng.pdf? sequence $=1$

19 Habibi R, Burci GL, de Campos TC, et al. Do not violate the International health regulations during the COVID-19 outbreak. The Lancet 2020;395:664-6.

20 Elbe S, Voelkner N. Viral Sovereignty: The Downside Risks of Securitising Infectious Diseases. In: Brown G, Yamey G, Wamala S, eds. Global health policy. London: Wiley \& Sons, 2014: 305-17.

21 Buckley C, Lee Myers S. As New Coronavirus Spread, China's Old Habits Delayed Fight. The New York Times [Internet], 2020 Available: https://www.nytimes.com/2020/02/01/world/asia/chinacoronavirus.html?searchResultPosition $=1$

22 Sridhar D, Gostin LO. Reforming the world Health organization. JAMA 2011;305:1585-6.

23 Shiffman J. Knowledge, moral claims and the exercise of power in global health. Int J Health Policy Manag 2014;3:297-9.

24 Frenk J, Moon S. Governance challenges in global health. N Engl J Med 2013;368:936-42.

25 Chonghaile C. Ebola spending: will lack of a positive legacy turn dollars into dolour? The Guardian 2015.

26 Kickbusch I, Reddy KS. Global health governance - the next political revolution. Public Health 2015;129:838-42.

27 Brown GW, Held D. In: Gridlock B, Hale T, Held D, eds. Global health: new leadership for devastating challenges. Cambridge: Polity Press, 2017: 162-83.

28 Swanson RC, Atun R, Best A, et al. Strengthening health systems in low-income countries by enhancing organizational capacities and improving institutions. Global Health 2015;11:5.

29 Organization for Economic Coordination and Development,. Working Party on aid effectiveness, task team on health as a tracer sector (OECD/WP EFF/TT-HATS). progress and challenges in aid effectiveness. What Can We Learn from the Health Sector? OECD/ WP EFF/TT-HATS 2011.

30 World Economic Forum. This is how much the coronavirus will cost the world's economy, according to the UN [Internet], 2020. Available: https://www.weforum.org/agenda/2020/03/coronavirus-covid-19cost-economy-2020-un-trade-economics-pandemic/ [Accessed cited 2020 Apr 1]

31 Evans RG, Barer ML, Marmor TR. Why are some people healthy and others not? The determinants of health of populations [Internet]. Taylor \& Francis, 1994. https://www.taylorfrancis.com/books/e/ 9781315135755
32 Marmot M. The health gap: the challenge of an unequal world: the argument. Int J Epidemiol 2017;46:1312-8.

33 Farmer P. Social inequalities and emerging infectious diseases. Emerg Infect Dis 1996;2:259-69.

34 Seeberg J, Meinert L. Can epidemics be non communicable? Reflections on the spread of 'noncommunicable' diseases. Medicine Anthropology Theory [Internet], 2015. Available: http:// www.medanthrotheory.org/read/5313/can-epidemics-be-noncommunicable

35 Swinburn BA, Kraak VI, Allender S, et al. The global Syndemic of obesity, undernutrition, and climate change: the Lancet Commission report. Lancet 2019;393:791-846.

36 Worldometer. Age, Sex, Existing Conditions of COVID-19 Cases and Deaths [Internet], 2020. Available: https://www.worldometers.info/ coronavirus/coronavirus-age-sex-demographics/ [Accessed cited 2020 Apr 1].

37 Ridde V, Ramel P. The migrant crisis and health systems: Hygeia instead of panacea. Lancet Public Health 2017;2:e447.

38 Muraille E. Why biodiversity is key to our survival [Internet]. The Conversation, 2018. Available: https://theconversation.com/whybiodiversity-is-key-to-our-survival-108184 [Accessed cited 2020 Apr 1].

39 Martineau AR, Jolliffe DA, Hooper RL, et al. Vitamin D supplementation to prevent acute respiratory tract infections: systematic review and meta-analysis of individual participant data. BMJ 2017;356:i6583.

40 Di Rosa M, Malaguarnera M, Nicoletti F, et al. Vitamin D3: a helpful immuno-modulator. Immunology 2011;134:123-39.

41 Muraille $E$. The unspecific side of acquired immunity against infectious disease: causes and consequences. Front Microbiol 2015;6:1525.

42 Harrison CA, Taren D. How poverty affects diet to shape the microbiota and chronic disease. Nat Rev Immunol 2018;18:279-87.

43 Duggal NA, Niemiro G, Harridge SDR, et al. Can physical activity ameliorate immunosenescence and thereby reduce age-related multi-morbidity? Nat Rev Immunol 2019;19:563-72.

44 Glaser R, Kiecolt-Glaser JK. Stress-Induced immune dysfunction: implications for health. Nat Rev Immunol 2005;5:243-51.

45 Julia V, Macia L, Dombrowicz D. The impact of diet on asthma and allergic diseases. Nat Rev Immunol 2015;15:308-22.

46 Scrimshaw NS. Historical concepts of interactions, synergism and antagonism between nutrition and infection. $J$ Nutr 2003;133:316S-21.

47 Pawson R, Tilley N. Realistic evaluation. London: Sage, 1997.

48 Garrett L. The coming plague: newly emerging diseases in a world out of balance. Farrar, Straus and Giroux. New York, 1994: 772.

49 Global Preparedness Monitoring Board. A world at risk: annual report on global preparedness for health emergencies [Internet] Geneva: World Health Organization (acting as the host organization for the Global Preparedness Monitoring Board), 2019. Available: https://apps.who.int/gpmb/assets/annual_report/GPMB_Annual_ Report_English.pdf

50 Eurostat. Healthcare resource statistics - beds [Internet], 2019. Available: https://ec.europa.eu/eurostat/statistics-explained/index. php/Healthcare_resource_statistics_-_beds

51 Broadbent A, Smart BTH. Why a one-size-fits-all approach to COVID-19 could have lethal consequences [Internet]. The Conversation, 2020. Available: https://theconversation.com/ why-a-one-size-fits-all-approach-to-covid-19-could-have-lethalconsequences -134252 ? fbclid=IwARONVcR9C2c0z9T4MuGOLX vDLxdJ7NM9ukAbRfWEJ9DdEEwMxDkLiz7N2ho

52 Parmet WE, Sinha MS. Covid-19 - the law and limits of quarantine. N Engl J Med Overseas Ed 2020;382:e28 https://www.nejm.org/doi/ full/

53 Gostin LO, Hodge JG. US Emergency Legal Responses to Novel Coronavirus: Balancing Public Health and Civil Liberties [Internet]. JAMA 2020 https://doi.org/ 